DOI

\title{
НЕПСИХОТИЧНІ ПСИХІЧНІ РОЗЛАДИ В ОСІБ, ЯКІ БРАЛИ УЧАСТЬ В ЗБРОЙНОМУ ПРОТИСТОЯННІ НА СХОДІ УКРАЇНИ
}

\author{
๑О. С. Юрценюк, С. С. Ротар \\ Буковинський державний медичний університет
}

РЕЗЮМЕ. Стаття присвячена дослідженню непсихотичних психічних розладів у учасників антитерористичної операції (АТО), комплексній діагностиці, лікуванню та психотерапії цих розладів в умовах стаціонару.

КЛЮчОВІ СлОВА: непсихотичні психічні розлади, діагностика, лікування.

Вступ. Протягом останнього року все більше лікарів різних спеціальностей по всій Україні серед своїх пацієнтів зустрічають вимушених переселенців та учасників бойових дій зі Сходу України. Такі події на території України розгортаються вперше за всі роки незалежності, тому вони $\epsilon$ незвичними, нетиповими, такими, що виходять за межі буденності. Це, у свою чергу, накладає значний відбиток на психічне життя українців, як тих, що перебувають в областях, де триває протистояння, так і в тих, де збережено мирний спосіб життя [1].

Період активного вивчення посттравматичного стресового розладу нараховує декілька десятиліть, однак інформація про переживання людей, на яких діяв стресогенний фактор, фіксується впродовж століть. Перші дослідницькі роботи проводились у Сполучених Штатах Америки, вони були направлені на вивчення особливостей переживання військового стресу під час громадянської війни в США. Про вплив війни на психіку солдата фахівці заговорили після військових дій США у В'єтнамі - виник так званий «в'єтнамський синдром». За даними медичного обстеження ветеранів війни у В'єтнамі, в 1988 році у 30,6 \% американців спостерігався посттравматичний стресовий розлад, у 22,5 \% - частковий. У 55,8 \% осі6, які мають посттравматичний синдром, були виявлені прикордонні нервово-психічні розлади, ймовірність опинитися безробітним у них в 5 разів більша, порівняно з іншими, розлучення були у $70 \%$, ізоляція від людей - у 47,3 \%, вираження ворожості - у 40 \%, потрапили до в'язниці або були заарештовані - 50 \% [3].

Відомо, що військовий стрес має хронічну причину та тенденцію до поступового погіршання з часом. Це підтверджується і дослідженнями сучасної науки, згідно з якими визначено, що у частини людей з наслідками військової травматизації симптоми посттравматичного стресового розладу (ПТСР) з часом посилюються. До діагностичних труднощів вияву ПтСР належить те, що він може проявитися як в період до одного місяця після травмуючої події, так і через 30-40 років.
Таким чином, головною особливістю ПТСР $є$ тенденція не тільки не зникати з часом, але й набувати більш вираженого характеру $[1,3]$.

Ситуація бойових дій призводить до виражених змін функціонального стану психічної діяльності, що характеризуються розвитком надзвичайно сильних негативних емоцій, таких як страх, тривога, тяжка розумова і фізична перевтома. У військовослужбовців в умовах бойових дій розвиваються психічні розлади, які визначають збірним терміном «посттравматичний стресовий розлад» (ПТСР). Відомо, що 98 \% військовослужбовців, які брали участь у бойових діях на території Чечні, страждають посттравматичним синдромом, а приблизно 30-35 \% солдатів мають алкогольну та/чи наркотичну залежність [4].

У сучасних реаліях та подіях, які відбуваються на Сході України, кожен другий боєць страждає від невротичних психічних розладів, пов'язаних зі стресом; ці порушення вже описують як «Донецький синдром» $[1,3,5]$.

Матеріал і методи дослідження. 3 метою вивчення структури непсихотичних психічних розладів у осіб, які брали участь в бойових діях АТО в період з 31.07.2014 року по 31.12.2014 року, було обстежено 147 чоловіків, які перебували на стаціонарному лікуванні у відділенні неврозів та пограничних станів Чернівецької обласної психіатричної лікарні. Середній вік обстежених становив 26,4 року. Мешканців села було 52,38 \%, смт $9,53 \%$, міста - 38,09\% осіб.

У процесі психодіагностичного дослідження з метою оцінки акцентуйованих властивостей особистості використовували опитувальник Г. Шмішека за концепцією К. Леонгарда. Ступінь виразності депресивної симптоматики оцінювали за допомогою шкали Гамільтона (Hamilton Depression Rating Scale, HDRS-21), тривожної симптоматики - за тестом Спілбергера-Ханіна. Також була використана шкала оцінки впливу травматичної події (Impact of Event Scale-Revised, IOES-R). Комплекс досліджень проводили при поступленні та безпосередньо після курсу лікування (через 1 місяць). 
Огляди літератури, оригінальні дослідження, погляд на проблему

Результати й обговорення. У структурі непсихотичних психічних розладів в учасників АТО переважали розлади адаптації (РА) - у 39,46 \%, ПТСР - у 28,58 \%, соматовегетативні розлади - у 19,04 \%, емоційно-вольові розлади -у 12,92 \%.

Аналізуючи особистісні особливості хворих 3 ПТСР та розладами адаптації (РА) ми встановили, що чистих типів акцентуації не було, проте в комбінаціях переважали застрягаючий, афективноекзальтований та циклотимічний типи акцентуації характеру; рідше - збудливий, гіпертимний, емотивний та педантичний типи. Дуже рідко дані розлади спостерігали у осіб з дистимічним та демонстративним типами.

Серед обстежених хворих більшість складали особи з високим рівнем особистісної тривожності (ВРОТ) - 59,0\% та пацієнти з середнім рівнем особистісної тривожності (СРОТ) - 38,0 \% випадків. Середнє значення ситуативної тривоги склало 44,49 бала. Прикметно, що рівень ситуативної та особистісної тривожності при первинному обстеженні (поступленні) був вищим, та вже через місяць комплексного лікування ситуативна тривожність знижувалась до помірного рівня, а особистісна залишалась високою. Слід звернути увагу на те, що у частини пацієнтів об'єктивно при огляді відмічалась тривожно-депресивна симптоматика, а результати тесту показували низький рівень тривожності, що може свідчити про високий рівень недовіри та брехні як захисного механізму.

ПТСР виникає лише в результаті переживання екстремальної події, а розлади адаптації - як внаслідок надзвичайних подій, так і під впливом стресу, який не сягає надзвичайного або катастрофічного рівня. Розвитку ПТСР і РА може передувати гостра стресова реакція. Диференційнодіагностичними критеріями даних розладів $\epsilon$ час їх формування (при ПТСР-через 1 місяць, при РАпротягом 1 місяця), існування латентного періоду (при ПТСР він обов'язковий, при РА - можливий), а також їх тривалість (при ПТСР вона необмежена, а при РА - не більше 6 місяців, за винятком пролонгованої депресивної реакції (F 43.21)).

Комплекс лікувально-реабілітаційних заходів для постраждалих включав медикаментозну терапію та психотерапію (ПТ). 3 ліків застосовували антидепресант (селективний інгібітор зворотного захоплення серотоніну), сертралін 50 мг вранці та, залежно від виразності тривожної симптоматики, паралельно призначали небензодіазепіновий анксіолітик афобазол - по 10 мг 3 рази на добу. 3 психотерапевтичних методів застосовували міліотерапію, раціональну, сімейну, когнітивно-біхевіоральну психотерапію та аутогенне тренування, спрямованість і зміст яких були диференційовані залежно від виявлених типів та виразності акцентуації, особливостей соціального статусу, актуальних психотравмувальних обставин тощо.

3 метою підтримки адаптивних навичок «я» найчастіше використовували наступні (індивідуальні, групові) техніки: систематична десенсибілізація; тренінги релаксації; зменшення зовнішніх вимог; техніки відновлення ресурсів «Я».

Для формування «позитивного ставлення» до симптому проводили ПТ, спрямовану на те, щоб допомогти пацієнтам зрозуміти, що їхні реакції нормальні, а пережите - це екстремальне. Це дозволяло запобігти подальшій травматизації людини вже самими хворобливими симптомами, а також актуалізувати власні особистісні ресурси.

Як відомо, для пацієнтів із ПТСР характерне навмисне уникання всього, що пов'язано з травмою: емоцій, спогадів, думок. У зв'язку з цим униканням травматичний досвід не переробляється, залишається хворобливим, а саме уникання стає додатковою проблемою, що загострює ситуацію.

Необхідною умовою ефективного лікування $\epsilon$ формування відчуття «контролю над травмою". Домінантою $є$ зміна змісту, що надається травматичній ситуації і її наслідкам. Багато авторів розглядають це відчуття як загальну кінцеву мету всіх психотерапевтичних втручань $[1,5]$.

Індивідуальні і групові форми терапії спрямовані на досягнення визначених терапевтичних цілей:

- повторне переживання травми в безпечному просторі з терапевтом (і групою);

- зниження почуття ізоляції і забезпечення почуття належності, доречності, загальних цілей, комфорту і підтримки, безпеки від почуття сорому;

- забезпечення соціальної підтримки і можливості розділити з іншими людьми емоційні переживання;

- спостереження за тим, як інші пацієнти (члени групи) переживають спалахи інтенсивних афектів;

- можливість бути в ролі того, хто допомагає, розвиток «почуття ліктя»;

- подолання почуття власної малоцінності;

- зменшення почуття провини або сорому, розвиток довіри, здатності розділити горе і втрату;

- можливість працювати з «секретом», ділитися з кимось інформацією про себе;

- зміцнення впевненості у тому, що прогрес у терапії можливий;

- одержати можливість скласти власне уявлення про реальність змін, які відбуваються 3 кожним членом групи [3].

Висновки. Наслідки воєнних дій на Сході України з усією очевидністю показують, наскільки учасникам бойових дій важлива допомога. 
Огляди літератури, оригінальні дослідження, погляд на проблему

Важливими є діагностика, лікування, корекція, профілактика та реабілітація пацієнтів з непсихотичними психічними розладами в учасників антитерористичної операції. Вирішення даної проблеми потребує комплексного підходу та повинно включати медикаментозну терапію та психотерапію. Початок терапевтичного втручання

повинен бути максимально раннім (з метою запобігання розвитку і хронізації захворювання) та мати тривалий характер.

Перспективи подальших досліджень. Проблема потребує подальшого всебічного і детального вивчення з метою надання якнайякіснішої допомоги хворим з ПТСР.

\section{ЛІТЕРАТУРА}

1. Стрес і людина: медико-психологічна допомога при стресових розладах : методичний посібник / за ред. І. Я. Пінчук, К. Д. Бабова, А. І. Гоженка. - К., 2014. - 91 с.

2. Посттравматичні стресові розлади: діагностика, лікування, реабілітація : методичні рекомендації / [уклад. : Волошин П. В. та ін.]. - Харків, 2002. - 47 с.

3. Діагностика, терапія та профілактика медикопсихологічних наслідків бойових дій в сучасних умовах : методичні рекомендації / [уклад. : Волошин П. В. та ін.]. - К., 2014. -67 c.

4. Шестопалова Л. Ф. Нарушения личностного функционирования у людей, переживших экстремальные события, и их психотерапевтическая коррекция / Л. Ф. Шестопалова, Д. М. Болотов, В. А. Кожевникова // Український медичний альманах. - 2004. - № 4 (додаток). - С. 123-126.

5. Психолого-психіатрична допомога постраждалим у збройних конфліктах : методичні рекомендації / [уклад. : Напрєєнко О. К. та ін.]. - К., 2014. - 26 с.

\section{NON-PSYCHOTIC MENTAL DISORDERS IN INDIVIDUALS PARTICIPATING IN ARMED CONFLICT IN THE EAST UKRAINE}

๑O. S. Yurtseniuk, S. S. Rotar

\section{Bukovynian State Medical University}

SUMMARY. The article deals with the non-psychotic mental disorders of the members of the counterterrorist operation (CTO), comprehensive diagnosis, treatment and therapy of these disorders in the hospital.

KEY WORDS: non-psychotic mental disorders, diagnosis, treatment.

Отримано 27.10 .2015 